\title{
Research and Practice on "Design Team” Model in Engineering Industrial Design
}

\author{
CHEN Hong \\ School of Mechatronic Engineering \\ Xi'an Technological University, XTU \\ Xi’an, China \\ Chenhong_xtu@yahoo.cn
}

\author{
ZHAO Peng \\ School of Mechatronic Engeering \\ Xi'an Technological University, XTU \\ Xi'an, China \\ rainbaby@163.com
}

\begin{abstract}
In view of the existing problems in the development of industrial design at engineering colleges, the paper proposed the design team model as an effective way to improve the students' practical ability. The design team model was formed in years of practice teaching reform exploration. The paper discussed the component types and main characteristics of the design team. And its achievements in school of mechatronic engineering at xi'an technological university were summarized.
\end{abstract}

Keywords- industrial design; practice teaching reform;design team; practical ability.

\section{INTRODUCTION}

Industrial design is an interdisciplinary subject. The students should master a lot of professional knowledge, including aesthetics, ergonomics, materials science, engineering, mechanics, psychology, marketing, sociology etc[1]. For industrial design graduates, more important is to design practical ability rather than empty talk.

The industrial design education has developed a few decades in China. There still have many blemishes. First, countries have been calling attention to the value of industrial design, and enterprise also realized it gradually. But due to realistic interests of the latent requirement and the positioning error of school education, the graduate capacity can not meet the market demand for design talent. At the same time, because the national intellectual property protection system is not perfect, many new research achievements of design in universities can not be guaranteed, and it's difficult to translate into subsequent survival fund. This leads to the shrinking of teachers and students in scientific research. This also leads to a "copycat" phenomenon ${ }^{[2]}$. Finally, the traditional teaching mode makes the design professional courses, which should have very strong interaction in the classroom, become quite satisfactory. And it makes students lack of independent innovation and learning lack of initiative. The class teaching is mainly theory teaching, and pays no attention to practice and practical ability, which makes the professional course study is not enough.

In recent years, some universities have gradually realized that the design education should strengthen the communication and cooperation with the enterprise, to promote the two-way communication between college research and business. Some domestic university, which devolop industrial design earlier, such as Academy of Fine Arts in Tsinghua University, Jiangnan University, widely used the "studio" model for teaching. At the same time, they strengthen cooperation with enterprises, and integrate the teaching resources.

For the talent training and education mode of engineering industrial design in school of mechatronic engineering at xi'an technological university, the following problems still exist:

1) Teaching mode can't meet the maket needs.

2) Students learn passively in the traditional teaching mode.

3) There is lack of the practicaL ability training in special design courses.

4) Engineering background resources have not been fully utilized.

The paper proposes the "design team" mode to solve these problems. The teachers introduce the actual subject in teaching. And the students can participate in the actual project through establishing design team. Students work together in practice. They will be familiar with the design process, understand the market demand, and enhance the application ability of the professional knowledge. It fully mobilize sstudents' initiative of learning, improves their design practical ability, and meets the enterprise demand for talents.

\section{THE MAIN TYPES OF DESIGN TEAM}

The formation of the design team is student-centered, interesting-centered, task-centered. The design team can fully mobilize students' learning initiative. And it can promote interaction of multiple grade and multidisciplinary students. The teaching mode has enhanced the students'practice ability and comprehensive quality. It is advantageous to train design talents in accordance with social requirements.

In practice, the industrial design professional teachers and class teacher can guide and promote the estabishment of design team. The design team also has many different forms to estabish, such as task oriented, multidisciplinary, multiple grade, special design, specific design etc. "Design team" is mainly in the self-management of students and the combination of teacher counseling supervision.

\section{A. Design team divided by project}

The design team is mainly formed through participation in design practice, from company or other training. This is similar to the project driven Teaching. It will add the real business subject to the curriculum teaching, and let students 
participate in the enterprise design projects. When the conditions are ripe, the student design team will be independently responsible for the enterprise design subject. In this project driving teaching, the teachers and enterprise designers jointly responsible for guidling students of the team. The teachers can undestand the actual situation in enterprise, to improve their teaching methods and content, during they guilding the students to design. The design process and the work of students can become the case for next class teaching. It has enriched the teacher's experience and the teaching content.

Students like this actual product design case. Students participate in product design, which let students understand the process of product design in enterprises. Students realize how to start and what to be considered for a specific product design. It promotes the students' team cooperation ability.

\section{B. Multidisciplinary product design team}

The team mainly composed of multidisciplinary students, mainly from industrial design and mechanical engineering. The practice forms of design includes design competition and graduation design.

Industrial design students pay more attention to product appearance design. Their innovative design ability and design skill are good, and the knowledge of product processing technology and engeering drawings is weak. On the contrary, the machinery manufacturing students are quite at the relationship with the product structure and function. But they pay no attention to the important product design content, including appearance, color collocation, interface etc. So their products appear very "machinery". Students of different majors together to complete the product design, it formed a multidisciplinary integrated design team.

In the specific design, students from industrial design and mechanical design participate in product conceptual design and structure design. After the mechaniam students complete product structure analysis and finite element analysis, the mold professional students complete the mold design of the product part. Then, the mechanism students complete the NC programming and Simulation Design. Finally , the industrial design students complete the product desigen and the final effect display. Under the guidance of the teacher, the students of different majors participate in different work. At the same time, they learn from each other. They exchange design and communication design method. Through the design process, students actively learned a lot of knowledge and teamwork, and they maked progress together.

\section{Multiple grade design team}

The team mainly consists of industrial design students in different grades. The Low grade students bring new ideas, and the high grade students can guide the professional course learning. Inside, the team members have common interests, which makes learning more efficient. They are learning in communication. Outside, they can undertake and complete a design task better.

Its main function is to cooperation and exchanges in various professional design field. Multiple grade design team can be divided by the special design field or interest. For example, the visual design team, color design team, model manufacture team, experience design team, modeling team etc. The design practice forms is mainly discipline competition, design competition and undertaking the related design project.

\section{THE MAIN FEATURES OF DESIGN TEAM}

The design team teaching mode in engeering industrial design, is an effective complement to traditional theory teaching. The mode fully mobilize students' learning initiative through the design practice of real guns and bullets. It give fully play to the resource advantages of the Faculty of engineering background.

\section{A. Focus on the design of educational origin}

The talent training purpose of design team teaching mode isn't just to pursue the perfect results. It will pay attention to the practical process. And though the design practical process, to enhance the innovation ability of students, to form a good personality, to enhance the artistic accomplishments.

\section{B. Emphasizes the initiative}

Active degree reflects one person's attitude how he looks at the world. It is the important influence factor to accomplish anything. The students who enjoy the design team should ensure their own initiative. Firstly, they should pay attention to the daily class learning in order to tamp the foundation. Then they can actively participate in all the work of design team. Only that can they ensure an all-round development.

\section{Humanization, team and open}

This is reflected in that integrating teacher counseling supervision into students' self management. The professional teacher and leader of the subject will occasionally directe and supervise the working study life of the design team. They will give the rectification to the team. Members of the design team put forward all kinds of problems in the practice. The professional teacher and leader of the subject will answer these questions. Based on the macro management mode, the student responsible person, who has be careful to pick out from the team, will be in charge of each transaction. The project will also be open to the students, who didn't enjoy the design team, during the project is in the process of executing. The students can be from industrial design or other subject. The project will get a very good solution through the teamwork and multidisciplinary cooperation, which will also cultivate students' cooperation ability.

\section{Complementarity}

Students of different grades have different professional foundation and different professional quality. Students in different majors have different knowledge structure, and their perspective to problem is different. And all the students are different in experience, hobbies, personality and specialty. So, Students can be complementary and mutualeffect through the daily common learning, work and practice. Then they will achieve common progress. The design team 
provides a platform for students. The platform is belong to the students self group, though which they can display their talent and improve their professional skills.

\section{PRELIMINARY ESTABLISHMENT AND PRACTICE OF DESIGN TEAM}

Since the design team of engeering industrial design started tentative plan and establishment., in school of mechatronic engineering, xi'an technological university. The team has experienced members' turnover and the adjustment of organization and management pattern. Now the team has formed a more clear method and a perfect way. And it has gain a lot of valuable practical experience and achievements. Such as the following outstanding design team: the product model making team, the small gear design team, the product innovative design team, and so on.

\section{A. The product model making team and its works}

The product model making team is starting from some students of grade 2007 and grade 2008 in industrial design together, and it has continued to the present. Figure 1 shows the key technologies and steps in the process of making clay model $^{[3]}$. Some clay model Works as shown in Figure 2.

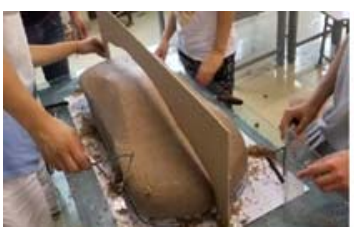

(a) The modification process

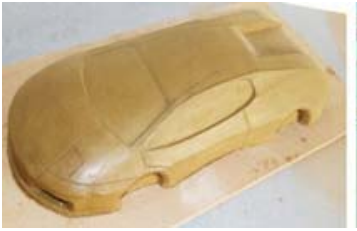

(a) Wax light model

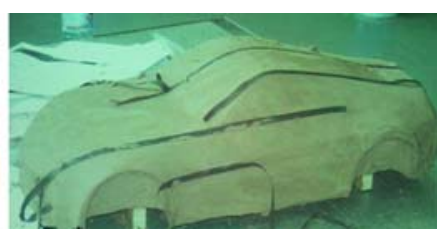

(b) The embedded process

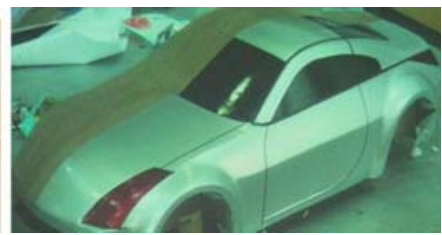

(b) Film mulching model
Figure 1. Clay modeling key technologies

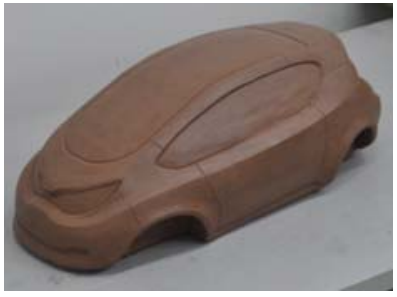

(a) Clay model work by MEI Zixun (grade 2008)

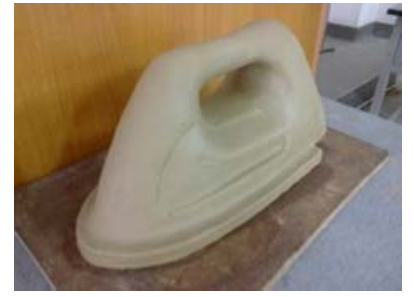

(b) Clay model work by ZHU Beiei and HUANG Xiaofang (grade 2009)
Figure 2. Clay model works by product model making team

\section{B. The small gear design team and its works}

The small gear design team formed by several students in industrial design majors of grade 2010. The small gear design team has participated in many design projects, including the logo design, packaging design, product design, multimedia design, user interface (UI) design, etc. The team would recruit some new members from other disciplines when they faced the new project. Their capacity has been greatly improved though the design practice. The small gear design team have achieved very good results and get a lot of excellent design works.

Figure 3 shows the work "The rotatable window" by the small gear design team. The design participants include three students of ingdustrial design, they are GAO Jie, MA Yuting and BAI Yu, and one student called LAI Hao in mechanical design. The rotatable window won the second prize in Shaanxi area at the fifth China Mechanical Innovation Design Competition for university students.

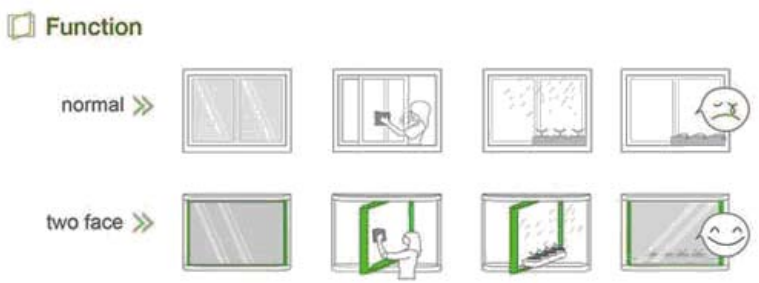

(a) Concept and function of the design

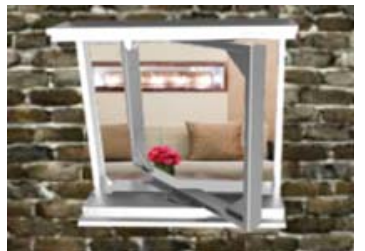

(b) Product effect picture

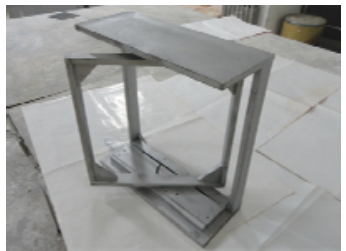

(C) Physical model photo
Figure 3. The rotatable window design by small gear design team

\section{The Product innovative design team and its works}

The product innovative design team set up by students from different grades. They focus on product innovation design method. And the creative product team get a lot of new product ideas. Its some works are as follows.

Figure 4 shows the modular sofa design concept by ZHANG Fang from grade 2008.
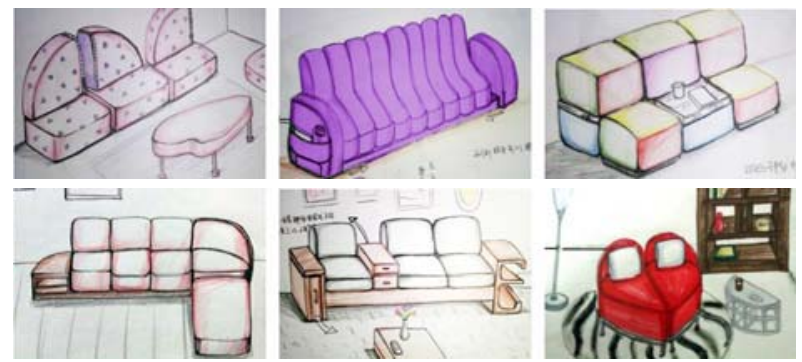

Figure 4. Concept and sketch drawing of modular sofa design

Figure 5 shows the breathing funnel design plan which designed by ZHU Beibei from grade 2009. 
Before

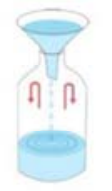

After

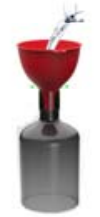

(a) Concept of the the breathing funnel design
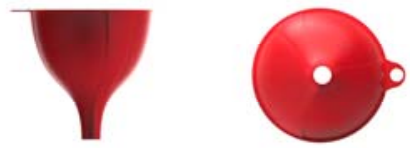

(b) Schematic diagram of the product structure detail

Figure 5. Concept and plan of the breathing funnel design

Figure 6 shows the design plan of double bed, which designed by LEI Lei from grade 2007.

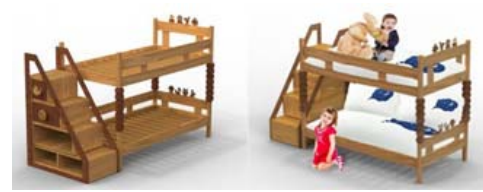

(a) Impression drawing of double bed

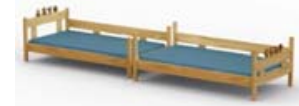

(b) Function expansion graph of the bed body
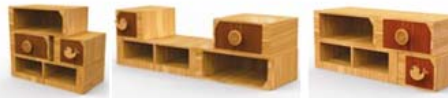

(a) Function expansion graph of the ladder cabinet Figure 6. The design plan of double bed

\section{CONCLUSIONS}

Exploration and practice of "design team" mode changed the old teaching mode which mainly knocked knowledge into students. The "design team" mode aroused the enthusiasm of the students. It lets the students participate in the process of teaching. Industrial design will return the correct teaching track which encourages design innovation and design practice. The new teaching mode meets the needs of industrial design specialty teaching, and adapts to the social design talent requirement. It is beneficial to enhance the students' comprehensive quality and to improve their design practice ability.

In the new situation, cultivating a student in industrial design, who has professional highquality, practical ability with a strong market awareness and in line with the labor demand of employing unit, should bases on school characteristics, student personality, professional requirements and so on.

\section{ACKNOWLEDGMENT}

This research was supported by teaching reform item funds of the Xi'an Technological University and granted No.12JGZ03.

\section{REFERENCES}

[1] YE Dehui, "Research on teaching reform of studio model in industrial design,” Guangxi Journal of Light Industry,Guilin, 2011, (11): 179180 , in chinese.

[2] ZHOU Meili, LI Yajun, "Exploration of design education cultivating model, the studio model of complementary study about multi-grade students in industrial ddesign,” Art and Design, Beijing, 2010, (3): 133-135, in chinese.

[3] ZHAO Peng, CHEN Hong, "Study on processing techniques of clay model in product design," Machinery Design \& Manufacture, Shenyang, 2012,(3): 240-242, in chinese. 